MBIA
p-ISSN 2086-5090, e-ISSN: 2655-8262
Vol. 18, No. 3, Desember 2019
Peringkat Akreditasi Sinta 5

\title{
Pengaruh Bauran Pemasaran Jasa dan Kepercayaan terhadap pembelian Online
}

\author{
Diah Isnaini Asiati \\ Universitas Muhammadiyah Palembang \\ Email:_diah_isnaini@yahoo.com \\ M. Hazazie Akbar \\ Universitas Muhammadiyah Palembang \\ Email:m.hazazieakbar07@gmaol.com
}

\begin{abstract}
The purpose of this study ia 1) to determine the effect of products, price, process and people on trsut 2) to determine the effect of products, price, process, people, and trsut in purchasing decesion 3) to determine the effect of trust on purchasng decesion. The type of research used is associate research, to determine the relationship between the marketing mix of service and trust in online purchasing decesion. The variables used are product, prive, process, people, trust, and purchasing decesion. The sample in this study was as many as 271 respondents, with cluster sampling sampling techniques. The data used in this study are primary data, using a questionnaire method. The analysis technique used is path analysis. The results of this study indicate that simultaneously 1) there are significant influence of of products, price, process and people on trsut 2) there is a significant influence of products, prices, processes, people, and trust in purchasing decisions 3 ) there is a significant influence of trust on purchasing decisions. As for partially 1) only price has a significant effect on trust, while products, processes and people have insignificant influence on trust 2) only price and trust have a significant influence on purchasing decisions, while product, price, process, and people have insignificant effect on purchasing decisions 3 ) there is a significant influence of trust on purchasing decisions.
\end{abstract}

Key words : product, price, process, people, trust, and purchasing decesion

\begin{abstract}
Abstrak
Tujuan penelitian ini adalah 1) untuk mengetahui pengaruh produk, harga, proses, dan orang terhadap kepercayaan pembelian online 2) untuk mengetahui pengaruh produk, harga, proses, orang, dan kepercayaan terhadap keputusan pembelian online. Jenis penelitian ini adalah asosiatif, guna menentukan keterkaitan antara bauan pemasaran jasa da kepercayaan dalam keptusan pembeilan online. Variabel yang digunakan adalah produk, harga, proses, orang, kepercayaan dan keputusan pembelian. Sampel penelitian berjumlah 271 orang yang dipilih secara cluster. Data yang digunakan adalah data primer dengan metode pengumpulan data kuesioner. Teknik analisis yang digunakan adalah analisis jalur. Hasil penelitian secara simultan menunjukkan 1) Terdapat pengaruh signifikan produk, harga, proses, dan orang terhadap kepercayaan pembelian online 2) Terdapat pengaruh signifikan produk, harga, proses, orang, dan kepercayaan terhadap keputusan pembelian. Adapun secara parsial 1) Hanya harga yang berpengaruh signifikan terhadap kepercayaan, sementara produk, proses, dan orang berpengaruh tidak signifikan terhadap kepercayaan pembelian online 2) Hanya harga yang berpengaruh signifikan terhadap keputusan pembelian, sementara produk, proses, orang, dan kepercayaan berpengaruh tidak signifikan terhadap keputusan pembelian online
\end{abstract}

Kata kunci: produk, harga, proses, orang, kepercayaan, keputusan pembelian

\section{Pendahuluan}

Teknologi komunikasi yang semakin maju dan berkembang menumbuhkan berbagai pengaruh bagi penggunanya. Masyarakat dituntut untuk lebih mampu memanfaatkan teknologi sesuai dengan fungsinya. Internet merupakan bentuk dari perkembangan teknologi yang saat ini sudah menjadi kebutuhan bagi sebagian kalangan. Penggunaan internet tidak hanya terbatas pada pemanfaatan informasi yang dapat diakses melalui media ini, melainkan juga dapat digunakan sebagai sarana untuk melakukan transaksi perdagangan dengan market place baru dan sebuah jaringan bisnis yang luas tidak terbatas waktu dan tempat. 


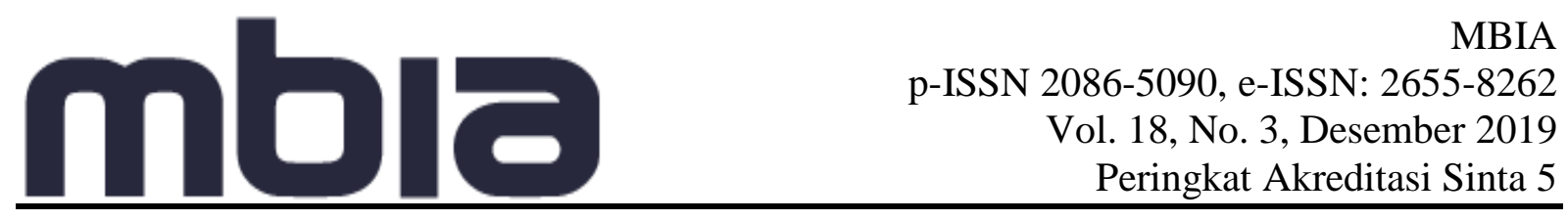

Meningkatnya transaksi berbelanja online di Indonesia tidak lepas dengan semakin banyaknya pemakaian internet. Hasil penelitian Liao dan Cheung (2010) di Singapura menunjukkan semakin banyak orang yang menggunakan internet maka ia semakin senang melakukan pembelian melalui $e$-shop. Dewasa ini, internet banyak digunakan sebagai media belanja dan pemasaran online suatu produk. Menurut Kotler dan Amstrong (2009), media pemasaran melalui internet atau sosial media lebih banyak diminati karena jangkauannya yang lebih besar dan luas dibandingkan dengan jaringan komersial lainnya. Dengan demikian media sosial dapat menjadi sebuah penghubung yang baik untuk intelijen pasar.

Tren pembelian online mulai diminati karena proses keputusan pembelian online tidak serumit keputusan pembelian offline. Pembelian online dapat menghemat waktu, menghemat biaya dan memudahkan kita dalam melakukan pembelian dibandingkan offline, yang harus mendatangi toko yang dituju. Trend belanja online juga menjadi fenomena baru dalam paradigma berbelanja mahasiswa saat ini. Proses terebut dapat dilakukan lewat media Instagram, Facebook, dan lain-lain.

Noefri dan Hafifah (2018) menemukan pengaruh faktor budaya, sosial, pribadi dan psikologis dalam melakukan online shopping. Hasil ini berbeda dibandingkan temuan Destian (2017) dimana diantara faktor budaya, sosial, pribadi dan psikologis, ternyata faktor pribadi tidak memberikan pengaruh yang bermakna. Wardoyo \& Andini (2017) juga melakukan kajian sejenis menggunakan dengan karakteristik konsumen sebagai sumbernya. Adapun Widiyanto \& Prasilowati (2015) menyoroti pembelian online karena daya tarik Web nya.

Pembelian online juga dilakukan karena pengaruh bauran pemasaran. Konsep bauran pemasaran secara tradisional (traditional marketing mix) terdiri dari 4P yaitu product (produk), price (harga), place (tempat), dan promotion (promosi). Sedangkan untuk pemasaran jasa (nontraditional marketing mix) terdapat 3P yaitu orang, bukti fisik dan proses. Bauran pemasaran jasa akan berjalan dengan optimal bila didukung dengan perencanaan yang terstruktur, hal tersebut mencakup kegiatan-kegiatan yang ada dalam bauran pemasaran jasa yang dimulai dari mengidentifikasi produk sebagai kebutuhan konsumen yang akan dipenuhi, menentukan harga, kegiatan promosi yang akan dilakukan, lokasi untuk memasarkan produk kepada konsumen, menetapkan orang yang terlibat dalam kegiatan usaha, serta mengatur proses yang akan digunakan dalam kegiatan usaha dan juga bukti fisik.

Selain itu kepercayaan merupakan faktor penting yang dapat mempengaruhi konsumen untuk membeli di Online shop. Hanya pelanggan yang memiliki kepercayaan dan akan berani melakukan transaksi melalui media internet. Dalam menampilkan produk terbaik dan dapat memenuhi selera konsumen yang selalu berkembang dan berubah-ubah sesuai dengan perkembangan trend.Tidak hanya pada kualitas layanan dan kepercayaan.Harga juga sangat mempengaruhi dalam keputusan konsumen. Konsumen mengharapkan harga dalam toko Onlinelebih rendah daripada toko offline (tradisional) sehingga konsumen mencari tahu perbandingan harga produk offline dan produk online.

\section{Landasan Teori}




\subsection{Perilaku Konsumen dan Keputusan Pembelian}

Menurut Kotler dan Keller (2012) perilaku konsumen adalah studi tentang bagaimana individu, dan bagaimana barang, jasa, ide, atau pengalaman untuk memuaskan kebutuhan dan keinginan mereka.

Menurut Tjiptono (2008) perilaku konsumen merupakan tindakan-tindakan individu yang secara langsung terlibat dalam usaha memperoleh, menggunakan, dan menentukan produk dan jasa, termasuk proses pengambilan keputusan yang mendahului dan mengikuti tindakantindakan tersebut.

Dengan demikian perilaku konsumen adalah tindakan yang dilakukan oleh individu, kelompok, atau organisasi yang berhubungan dengan proses pengambilan keputusan dalam mendapatkan, menggunakan barang atau jasa ekonomi yang dapat dipengaruhi lingkungan.

Kotler \& Keller (2012) menjelaskan bahwa secara garis besar perilaku konsumen dipengaruhi oleh: (1) Rangsangan Pemasaran yang terdiri dari produk dan jasa, harga, tempat dan komunikasi (2) Rangsangan Lain yaitu ekonomi, teknologi, dan persepsi; (3) Karakteristik Konsumen yaitu budaya, sosial, pribadi, dan psikologis; (4) Proses Keputusan Pembelian yang dimulai sejak pengenalan masalah sampai perilaku pasca pembelian.

Berbagai pengaruh tersebut akan mengarahkan konsumen pada keputusan pembelian. Menurut Schiffman dan Kanuk (2009), keputusan pembelian merupakan pemilihan suatu tindakan dari dua alternatif atau lebih. Sedangkan menurut Assael (2006), pengambilan keputusan pembelian adalah proses penilaian dan pemilihan dari berbagai alternatif sesuai dengan kepentingankepentingan tertentu dengan menetapkan suatu pilihan yang dianggap paling menguntungkan

Kotler \& Keller (2012) menyatakan bahwa setiap keputusan pembelian mempunyai struktur sebanyak tujuh komponen yaitu keputusan tentang jenis produk, keputusan tentang bentuk produk, keputusan tentang merek, keputusan tentang penjualan, keputusan tentang jumlah produk, keputusan tentang waktu pembelian.

\subsection{Bauran Pemasaran Jasa}

Program pemasaran yang efektif memadukan seluruh elemen bauran pemasaran kedalam suatu program terpadu yang didesain untuk mencapai tujuan-tujuan pemasaran perusahaan. Bauran pemasaran menciptakan seperangkat alat taktis perusahaan untuk membangun posisi yang kuat didalam pasar sasaran. Unsur-unsur bauran pemasaran jasa menurut Zeithaml, Bitner, dan Gremler (2013), terdiri dari 7P yaitu: (1) Produk (product) adalah segala sesuatu yang ditawarkan ke suatu pasar untuk memenuhi segala keinginan dan kebutuhan konsumen; (2) Tempat/lokasi (place), adalah berbagai kegiatan yang dilakukan perusahaan agar produk atau jasa dapat diperoleh dan tersedia bagi pasar sasaran; (3) Harga (price), adalah sejumlah uang yang dikeluarkan konsumen untuk memperoleh produk atau jasa yang dihasilkan perusahaan; (4) Promosi (promotion), adalah semua kegiatan yang dilakukan untuk mengkomunikasikan dan memperomosikan produk atau jasa kepasar sasaran; (5) Orang (people), adalah semua pelaku yang memainkan peranan dalam penyajian jasa sehingga dapat mempengaruhi persepsi pembali; (6) Bukti fisik (physical evidence), adalah lingkungan fisik dimana jasa disampaikan dan dimana perusahaan dan konsumennya berinteraksi dan setiap komponen tangible memfasilitasi penampilan atau komunikasi dari jasa tersebut; (7) Proses (process), adalah seluruh aktivitas kerja dimana melibatkan prosedur, tugas - tugas, jadwal - jadwal, mekanisme 


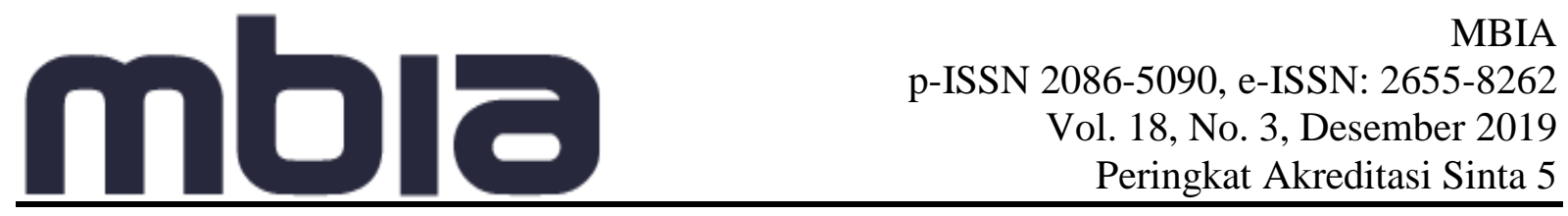

- mekanisme, kegiatan - kegiatan dan rutinitas - rutinitas dengan apa produk (barang atau jasa) disalurkan ke pelanggan.

\subsection{Kepercayaan}

Menurut Sirdeshmukh (2002) kepercayaan adalah sebagian harapan yang dimiliki konsumen bahwa penyedia layanan dapat dianndalkan untuk memenuhi janjinya. Kepercayaan juga dapat diperoleh karena melakukan suatu hal yang terbaik kepada pihak lain melalui suatu hubungan. Sedangkan Moorman \& Zaltman (1993) mendefinisikan kepercayaan (trust) sebagai kemauan untuk bergantung pada penjual yang dapatdipercaya.

Koufaris dan Hampton Sosa (2004) menyatakan bahwa kepercayaan konsumen akan $e$ commerce merupakan salah satu faktor kunci dalam melakukan kegiatan jual beli secara online. Kepercayaan merupakan salah satu fondasi dari bisnis apapun, suatu transaksi bisnis antara dua belah pihak atau lebih akan terjadi apabila masing-masing pihak saling mempercayai. Kepercayaan ini tidak begitu saja dapat diakui oleh pihak lain/mitra bisnis, melainkan harus dibangun mulai dari awal dan dapat dibuktikan. Menurut Moorman \& Zaltman (1993) kepercayaan merupakan kesediaan individu untuk menggantungkan dirinya pada pihak lain yang terlibat dalam pertukaran karena individu mempunyai keyakinan kepada pihak lain.

Kepercayaan dalam bisnis online memiliki peranan yang penting, karena menurut (Mahkota dkk, 2014), menyimpulkan bahwa semakin tinggi derajat kepercayaan konsumen, semakin tinggi tingkat niat pembelian konsumen. Cukup percaya ketika melakukan belanja online dan ketika pelanggan mengirimkan informasi keuangan dan data pribadi lainnya dalam melakukan transaksi keuangan.

Penelitian Mahkota, et al. (2014), Pengaruh Kepercayaan Dan Kenyamanan Terhadap Keputusan Pembelian Online (Studi Pada Pelanggan Website Ride Inc). Tujuan penelitian ini adalah untuk mengetahui Pengaruh Kepercayaan Dan Kenyamanan Terhadap Keputusan Pembelian Online (Studi Pada Pelanggan Website Ride Inc).Variabel yang digunakan adalah variabel keputusan pembelian, kepercayaan, kenyamanan.Sampel yang digunakan dalam penelitian ini sejumlah 150 responden. Metode pengambilan sampel yang dilakukan dengan cara Accidental Sampling. Data yang digunakan adalah analisis kualitatif. Hasil penelitian menunjukan bahwa variabel kepercayaan dankenyamanan berpengaruh secara signifikan terhadap keputusan pembelian Online.

\section{Metodologi Penelitian}

Jenis penelitian ini adalah penelitian asosiatif (Sugiyono, 2016), yaitu penelitian dengan bentuk hubungan kausal (hubungan sebab akibat), yang merupakan bagian dari penelitian eksplanasi (penjelasan) dengan tujuan menjelaskan kedudukan variabel-variabel yang diteliti serta hubungan antara satu variabel dengan variabel yang lain. Lokasi pada penelitian ini dilaksanakan di Universitas Muhammadiyah Palembang.

Penelitian menggunakan variabel stimuli pemasaran jasa (produk, harga, proses, orang) dan variabel karakteristik konsumen (kepercayaan) yang diuji pengaruhnya terhadap keputusan pembelian. Setiap variabel dikembangkan masing-masing menjadi empat indikator sehingga terdapat 24 indikator sebagai basis analisis. 
Populasi penelitian adalah sebanyak 7.930 mahasiswa UMP. Sampel ditentukan berdasarkan tabel (Sugiyono, 2016) dengan tingkat kesalahan sebesar 10\% diperoleh 271 mahasiswa. Teknik Sampling yang digunakan pada penelitian ini adalah Cluster Sampling. Data yang diperlukan adalah data primer.dengan teknik pengumpulan data daftar pertanyaan (kuesioner) yang berhubungan dengan indikator yang digunakan. Data tersebut selanjutnya dianalisis menggunakan teknik Path Analysis.

\section{Hasil Dan Pembahasan}

a. Gambaran Karakteristik Responden

Responden penelitian ini terdiri dari 45,1\% laki-laki dan 54,9\% perempuan, yang proposional berasal dari semua Fakultas di lingkungan UMP. Sebagian besar responden tengah berada di semester $3(26,93 \%)$, berturut-turut selanjutnya semester $5(23,98 \%)$, semester $7(19,92)$, semester $1(19,55 \%)$, dan semseter $9(19,92 \%)$.

\section{b. Proses Pengujian}

\section{Hasil Regresi Linier Berganda Sub Struktur 1}

\section{Tabel 1. Model Summary}

\begin{tabular}{|l|r|r|r|r|}
\hline $\begin{array}{l}\text { Mode } \\
1\end{array}$ & R & R Square & $\begin{array}{c}\text { Adjusted R } \\
\text { Square }\end{array}$ & $\begin{array}{r}\text { Std. Error of } \\
\text { the Estimate }\end{array}$ \\
\hline 1 &, $236^{\mathrm{a}}$ &, 056 &, 041 &, 84863 \\
\hline
\end{tabular}

a. Predictors: (Constant), Orang, Produk, Proses, Harga

Berdasarkan Tabel.1, tampak produk, harga, proses, dan orang memiliki korelasi sebesar 0,236. Koefisien determinasi menunjukkan bahwa produk, harga, proses, dan orang mampu menjelaskan penyebab keputusan pembelian online sebesar $4,1 \%$, sedangkan sisanya sebesar 95,9\% dipengaruhi variabel lain yang tidak masuk dalam penelitian ini.

Tabel 2. ANOVA ${ }^{\mathrm{a}}$

\begin{tabular}{|l|r|r|r|r|r|}
\hline Model & \multicolumn{1}{|c|}{$\begin{array}{c}\text { Sum of } \\
\text { Squares }\end{array}$} & df & \multicolumn{1}{c|}{$\begin{array}{c}\text { Mean } \\
\text { Square }\end{array}$} & F & Sig. \\
\hline Regression & 11,295 & 4 & 2,824 & 3,921 &, $004^{\mathrm{b}}$ \\
Residual & 191,565 & 266 &, 720 & & \\
Total & 202,859 & 270 & & & \\
\hline
\end{tabular}

a. Dependent Variable: Percaya

b. Predictors: (Constant), Orang, Produk, Proses, Harga

Tabel 2 menunjukkan bahwa pengaruh produk, harga, proses, dan orang secara bersama-sama terhadap kepercayaan adalah nyata, terbukti dengan nilai Sig F $0,004<\alpha=0,05$

Tabel 3. Coefficients ${ }^{\mathrm{a}}$

\begin{tabular}{|l|c|c|c|c|}
\hline Model & $\begin{array}{c}\text { Unstandardized } \\
\text { Coefficients }\end{array}$ & $\begin{array}{c}\text { Standardized } \\
\text { Coefficients }\end{array}$ & $\mathrm{t}$ & Sig. \\
\cline { 2 - 4 }
\end{tabular}




\begin{tabular}{|c|c|c|c|c|c|c|}
\hline & & B & Std. Error & Beta & & \\
\hline \multirow{5}{*}{1} & (Constant) & $\overline{1,389}$ &, 389 & & 3,571 & 000 \\
\hline & Produk &, 063 & 070 & 055 & ,891 & ,374 \\
\hline & Harga & 205 & ,080 & , 160 & 2,567 & 011 \\
\hline & Proses &, 062 & ,066 & ,058 & ,946 &, 345 \\
\hline & Orang & ,121 & ,070 & ,105 & 1,725 & ,086 \\
\hline
\end{tabular}

a. Dependent Variable: Percaya

Berdasarkan Tabel 3, hanya harga yang memberikan pengaruh signifikan terhadap kepercayaan dengan sig $\mathrm{t}=0,011<\alpha=0,05$, sedangkan produk, harga, dan proses secara parsial berpengaruh tidak signifikan terhadap kepercayaan dengan sig $\mathrm{t}$ masing-masing sebesar $0,374,0,345$, dan 0,086 yang semuanya lebih kecil dibandingkan $\alpha=0,05$.

\section{Hasil Regresi Linier Berganda Sub Struktur 2}

Tabel 4. Model Summary

\begin{tabular}{|l|r|r|r|r|}
\hline Model & R & R Square & $\begin{array}{c}\text { Adjusted R } \\
\text { Square }\end{array}$ & $\begin{array}{c}\text { Std. Error of } \\
\text { the Estimate }\end{array}$ \\
\hline 1 &, $265^{\mathrm{a}}$ &, 070 &, 053 & 1,04284 \\
\hline
\end{tabular}

a. Predictors: (Constant), Percaya, Produk, Proses, Orang, Harga

Berdasarkan Tabel.4, tampak produk, harga, proses, orang, dan kepercayaan memiliki korelasi sebesar 0,265. Koefisien determinasi menunjukkan bahwa produk, harga, proses, orang, dan kepercayaan mampu menjelaskan penyebab keputusan pembelian online sebesar 5,3\% , sedangkan sisanya sebesar 94,7\% dipengaruhi variabel lain yang tidak masuk dalam penelitian ini.

Tabel 5. ANOVA ${ }^{\mathrm{a}}$

\begin{tabular}{|l|r|r|r|r|r|}
\hline Model & \multicolumn{1}{|c|}{$\begin{array}{c}\text { Sum of } \\
\text { Squares }\end{array}$} & df & $\begin{array}{c}\text { Mean } \\
\text { Square }\end{array}$ & F & Sig. \\
\hline Regression & 21,845 & 5 & 4,369 & 4,017 &, $002^{\mathrm{b}}$ \\
Residual & 288,190 & 265 & 1,088 & & \\
Total & 310,035 & 270 & & & \\
\hline
\end{tabular}

a. Dependent Variable: Kpts Pemb

b. Predictors: (Constant), Percaya, Produk, Proses, Orang, Harga

Tabel 5 menunjukkan bahwa pengaruh produk, harga, proses, orang, dan kepercayaan secara bersama-sama terhadap keputusan pembelian adalah nyata, terbukti dengan nilai Sig F 0,002< $\alpha=0,05$

\section{Tabel 6. Coefficients ${ }^{\mathrm{a}}$}




\begin{tabular}{|c|c|c|c|c|c|}
\hline \multirow[t]{2}{*}{ Model } & \multicolumn{2}{|c|}{$\begin{array}{l}\text { Unstandardized } \\
\text { Coefficients }\end{array}$} & $\begin{array}{l}\text { Standardized } \\
\text { Coefficients }\end{array}$ & \multirow[t]{2}{*}{$\mathrm{t}$} & \multirow[t]{2}{*}{ Sig. } \\
\hline & B & Std. Error & Beta & & \\
\hline (Constant) & 1,317 & ,489 & & 2,692 & ,008 \\
\hline Produk & ,040 & ,087 & ,028 & ,465 & ,642 \\
\hline Harga & ,277 & ,099 & , 175 & 2,780 & ,006 \\
\hline Proses & ,059 & ,081 & ,044 & ,721 & ,471 \\
\hline Orang & 045 & ,087 & ,031 & ,519 & 604 \\
\hline Percaya & ,165 &, 075 & ,133 & 2,189 & ,029 \\
\hline
\end{tabular}

a. Dependent Variable: Kpts Pemb

Berdasarkan Tabel 6, hanya harga dan kepercayaan yang memberikan pengaruh signifikan terhadap keputusan pembelian dengan sig $\mathrm{t}=0,006$ dan $0,029<\alpha=0,05$, sedangkan produk, harga, dan proses secara parsial berpengaruh tidak signifikan terhadap keputusan pembelian dengan sig $\mathrm{t}$ masing-masing sebesar $0,642,0,471$, dan 0,604 yang semuanya lebih kecil dibandingkan $\alpha=0,05$.

\section{Hasil Regresi Sub Struktur 3}

Tabel 7. Model Summary

\begin{tabular}{|l|r|r|r|r|}
\hline Model & \multicolumn{1}{|c|}{$\mathrm{R}$} & R Square & Adjusted R Square & \multicolumn{1}{c|}{$\begin{array}{c}\text { Std. Error of the } \\
\text { Estimate }\end{array}$} \\
\hline 1 &, $178^{\mathrm{a}}$ &, 032 &, 028 & 1,056 \\
\hline
\end{tabular}

a. Predictors: (Constant), Kepercayaan

Berdasarkan Tabel.7, tampak kepercayaan memiliki korelasi sebesar 0,178. Koefisien determinasi menunjukkan bahwa kepercayaan mampu menjelaskan penyebab keputusan pembelian online sebesar $2,8 \%$, sedangkan sisanya sebesar $97,2 \%$ dipengaruhi variabel lain yang tidak masuk dalam penelitian ini.

Tabel 8. Coefficients ${ }^{\mathrm{a}}$

\begin{tabular}{|l|r|r|r|r|r|}
\hline Model & \multicolumn{2}{|c|}{$\begin{array}{c}\text { Unstandardized } \\
\text { Coefficients }\end{array}$} & $\begin{array}{c}\text { Standardized } \\
\text { Coefficients }\end{array}$ & \multirow{2}{*}{ Sig. } \\
\cline { 2 - 4 } & \multicolumn{1}{|c|}{$\mathrm{B}$} & Std. Error & Beta & & \\
\hline (Constant) & 2,494 &, 220 & & 11,350 &, 000 \\
Kepercayaan &, 221 &, 074 &, 178 & 2,973 &, 003 \\
\hline
\end{tabular}

a. Dependent Variable: Kpts_Pemb

Berdasarkan Tabel 8,kepercayaan memberikan pengaruh signifikan terhadap keputusan pembelian dengan sig $\mathrm{t}=0,000<\alpha=0,05$.

\section{Tabel 9. Rangkuman Hasil Pengujian}




\begin{tabular}{|c|c|c|c|}
\hline Hubungan Antar Variabel & $\begin{array}{l}\text { Pengaruh } \\
\text { Langsung } \\
\text { (a) }\end{array}$ & $\begin{array}{c}\text { Pengaruh } \\
\text { Tidak } \\
\text { Langsung } \\
\text { (lewat } \\
\text { kepercayaan) } \\
\text { (b) }\end{array}$ & $\begin{array}{c}\text { Pengaruh Total } \\
(\mathbf{a}+\mathbf{b})\end{array}$ \\
\hline $\begin{array}{l}\text { Produk----Keputusan } \\
\text { Pembelian }\end{array}$ & 0,040 & $0,040 \times 0,063$ & $\begin{array}{l}0,040+0,00252=0,0425 \\
2\end{array}$ \\
\hline $\begin{array}{l}\text { Harga----Keputusan } \\
\text { Pembelian }\end{array}$ & 0,277 & $0,277 \times 0,205$ & $\begin{array}{l}0,277+0,056785=0,333 \\
785\end{array}$ \\
\hline $\begin{array}{l}\text { Proses----Keputusan } \\
\text { Pembelian }\end{array}$ & 0,059 & $0,059 \times 0,062$ & $\begin{array}{l}0,059+0,003658=0,062 \\
658\end{array}$ \\
\hline $\begin{array}{l}\text { Orang----Keputusan } \\
\text { Pembelian }\end{array}$ & 0,045 & $0,045 \times 0,121$ & $\begin{array}{l}0,045+0,005445=0,050 \\
445\end{array}$ \\
\hline $\begin{array}{l}\text { Kepercayaan------ } \\
\text { Keputusan Pembelian }\end{array}$ & 0,165 & & 0,165 \\
\hline
\end{tabular}

Sumber : Rangkuman hasil pengujian, 2018

\section{c. Pembahasan Hasil Penelitian}

\section{Pengaruh Produk Terhadap Keputusan Pembelian Online dengan Kepercayaan sebagai Intervening.}

Berdasarkan hasil pengujian, produk berpengaruh tidak signifikan baik secara langsung maupun secara tidak langsung (lewat kepercayaan) terhadap keputusan pembelian online.Kotler \& Amstrong (2009) menyatakan bahwa produk termasuk salah satu faktor yang berpengaruh terhadap keputusan pembelian.

Ragam dan kualitas produk tampaknya belummenjadi daya tarik utama dalam pembelian online. Asiati \& Eljalina (2017) menyatakan bahwa, dalam melakukan pembelian online umumnya konsumen melakukannya bukan karena melihat produk yang akan dibeli secara online. Akan tetapi, konsumen tertarik dengan produk yang digunakan oleh orang lain, baru kemudian melakukan pembeliannya secara online.

\section{Pengaruh Harga Terhadap Keputusan Pembelian Online dengan Kepercayaan sebagai Intervening.}

Berdasarkan hasil pengujian, harga berpengaruh positif dan signifikan secara langsung maupun secara tidak langsung (melalui kepercayaan) terhadap keputusan pembelian online. Hal ini sejalan dengan pendapat Kotler \& Amstrong (2009) menyatakan bahwa, harga merupakan salah satu unsur bauran pemasaran yang berpengaruh terhadap keputusan pembelian.Ini berarti hasil pengujian hipotesis sejalan dengan teori tersebut..

Hasil penelitian juga sejalan dengan hasilpenelitian Verina dkk (2014) produk punya pengaruh tidak signifikan terhadap keputusan pembelian.Ketika melakukan pembelian online, konsumen menilai produk tidak sekedar lewat bukti fisik yang diterimanya. Akan tetapi kemudahannya 


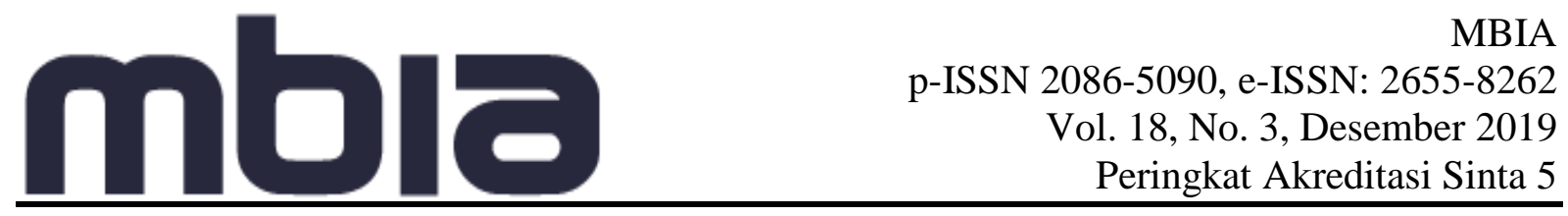

memperoleh barang tersebut (diantar sampai rumah) merupakan pengalaman yang menyenangkan. Harga barang-barang online biasanya juga relatif lebih murah dibandingkan barang-barang yang dibeli langsung ke toko sehingga harga juga menjadi pertimbangan konsumen untuk melakukan pembelian online.

\section{Pengaruh Proses Terhadap Keputusan Pembelian Online dengan Kepercayaan sebagai Intervening.}

Berdasarkan hasil pengujian terdapat pengaruh positif dan tidak signifikan proses terhadap keputusan pembelian online baik secara langsung maupun secara tidak langsung (lewat kepercayaan).Secara teori, Lovelock \& Right (2009) menyatakan bahwa, proses merupakan salah satu unsur bauran pemasaran jasa yang berpengaruh terhadap keputusan pembelian. Tetapi dalam penelitian Verina dkk (2014) harga berpengaruh tidak signifikan. Barangkali karena Verina dkk melakukan penelitian pada tahun 2014, sehingga konsumen belum terbiasa melakukan pembelian online dan sehingga harga belum dipertimbangkan sebagai salah satu daya tarik pembelian online.

Proses tidak mempunyai pengaruh signifikan. Penjualan online dapat dilakukan dengan mudah, akan tetapi banyak yang menyangkal kecepatan sampainya barang dan kepraktisannya. Berbeda dengan pembelian di toko yang memungkinkan barang langsung diterima, pembelian online memang memerlukan waktu sampainya/diterimanya barang. Barangkali karena sudah membayar, konsumen maunya sesegera mungkin barang datang sehingga waktu tunggu yang sebentar pun tidak ditolerirnya. Itulah sebabnya proses tidak memberikan pengaruh signifikan terhadap keputusan pembelian online.Sistem ini dinilai kurang memiliki daya kecepatan untuk merespon apa yang diinginkan pembeli.

\section{Pengaruh Orang Terhadap Keputusan Pembelian Online dengan Kepercayan sebagai Intervening.}

Berdasarkan hasil pengujian, terdapat pengaruh positif dan tidak signifikan orang terhadap keputusan pembelian online baik secara langsung maupun secara tidak langsung (lewat kepercayaan). Secara teori, Kotler \& Amstrong (2009) menyatakan bahwa, bauran pemasaran jasa $(4 \mathrm{P}+3 \mathrm{P})$ mempengaruhi keputusan pembelian. Unsur 3P adalah process, people, dan physical evedence. Dengan demikian orang/people merupakan salah satu unsur bauran pemasaran yang berpengaruh terhadap keputusan pembelian. Variabel orang yang dinyatakan tidak signifikan disebabkan karena orang yang terlibat dalam penjualan online tidak memiliki layanan kualitas yang baik dengan pembeli sehingga kualiatas minat pembeli sedikit.

Hasil penelitian tidak sejalan dengan penelitian Verina dkk (2014), bahwa orang berpengaruh signifikan terhadap keputusan pembelian, hal ini dikarenakan orang dalam bauran jasa tidak merespon secara cepat apa yang diinginkan pembeli. Penelitian Verina dkk dilakukan pada tahun 2014 ketika orang belum terbiasa melakukan pembelian online. Dalam situasi tersebut, orang mungkin melakukan pembelian online berdasarkan referensi banyak orang (karena belum terbiasa, baru mencoba) sehingga berbagai referensi inilah yang dinilai sebagai orang. Padahal sebetulnya yang dimaksud dengan orang adalah penjual.

Konsumen menilai penjual tidak dapat merespon dengan cepat dan tidak dapat menjelaskan produk yang kurang dimengerti oleh konsumen. Pada dasarnya penjualan online hampir tanpa dialog pembeli-penjual, padahal mungkin banyak yang ingin dutanyakan konsumen. Itulah sebabnya bertemu dan mendapatkan penjelasan dari penjual (=orang) berpengaruh tidak 


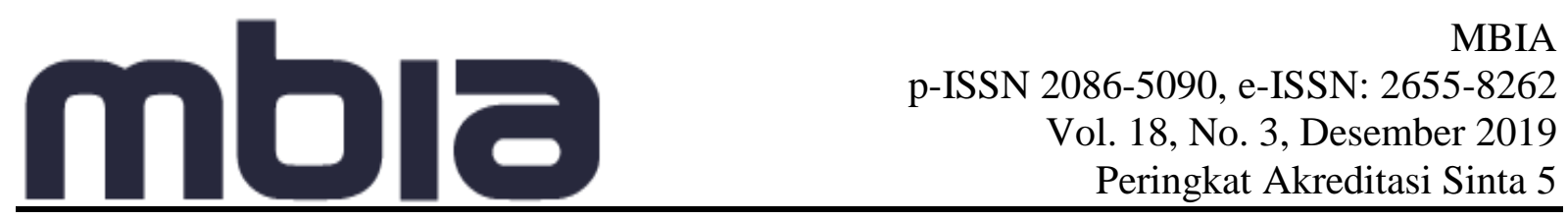

signifikan terhadap keputusan pembelian online.Saran yang dapat diberikan adalah, karena penjualan online tidak memungkinkan adanya intereaksi aktif antara pembeli dan penjual, maka sebaiknya disediakan informasi detail untuk konsumen sehingga konsumen mengetahui informasi-informasi yang diinginkannya.

\section{Pengaruh Kepercayaan Terhadap Keputusan Pembelian.}

Berdasarkan hasil pengujian, terdapat pengaruh positif dan signifikan kepercayaan terhadap keputusan pembelian online.Secara teori, Kotler \& Amstrong (2009) menyatakan bahwa, karakteristik pembeli juga berpengaruh terhadap keputusan pembelian. Diantara karakteristik pembeli adalah faktor budaya, sosial, pribadi, dan psikologis. Kepercayaan ada dalam faktor pribadi.

Hasil ini sejalan dengan penelitian sebelumnya yang dilakukan oleh Verina dkk (2014), Mahkota (2014),),bahwa kepercayaan berpengaruh terhadap keputusan pembelian online di Univeritas Muhammadiyah Palembang.

\section{Simpulan}

Berdasarkan hasil pembahasan, maka dapat ditarik kesimpulan bahwa adanya pengaruh signifikan bauran jasa (produk, harga, proses, orang dan kepercayaan) terhadap keputusan pembelian online. Sedangkan uji secara parsial harga dan kepercayaan berpengaruh signifikan terhadap keputusan pemeblian, sedangkan tiga variabel yaitu produk $\left(\mathrm{X}_{1}\right)$, proses $\left(\mathrm{X}_{3}\right)$ dan orang $\left(\mathrm{X}_{4}\right)$ yang tidak berpengaruh signifikan terhadap keputusan pembelian.

\section{Daftar Pustaka}

Asiati, Diah Isnaini \& Eljalina. 2017. Pengaruh Bauran Pemasaran dan Karakteristik Pembeli terhadap Keputusan Pembelian. Jurnal Balance XIV(2) : $71-82$ file:///C:/Users/ASUS/Downloads/1331-4840-1-PB.pdf

Assael, Henry. 2006. Consumer Behavior and Marketing Action. USA : South Westen Publishing Company

Destian, Surya. 2017. PengaruhPerilaku Konsumen (budaya, sosial, pribadi, dan psikologis) terhadap Keputusan pembelian Online pada Situs Modifikasi.Com Kota Bandung. $e$ Proceedeng of Management 4(3): p.2434 (1-8)

Koufaris, M \& Hampton-Sosa. 2004. The Development of Initial Trust in an Online Company by New Customers. Information \& Management $41:$ 377-397.

Kotler \& Keller. 2012. Manajemen Pemasaran Edisi Kesebelas. Jakarta: Gramedia Lovelock, Christopher, Jochen Wirtz, \& Jacky Mussry. 2012.Pemasaran Jasa. Edisi 7. Erlangga: Jakarta

Liao, Z., dan Cheung, M. T. (2001). An Analytical Framewok for Evaluating E-commerce Business Models and Strategis. Internet Research: Electronic Networking Applications and Policy. Vol. 11, No. 4

Lovelock, Christopher H Lauren K Wright. 2009. Manajemen Pemasaran Jasa. Jakarta : PYT Indeks

Mahkota, AP, Suyadi I \& Riyadi. 2014. Pengaruh Kepercayaan dan Kenyamanan terhadap Keputusan Pembelian Online (Studi Pada pelanggan Website Ride Inc) Jurnal Administrasi Bisnis 57(1) : 1-7

Moorman, CR Deshpande \& G. Zaltman. 1993. Factor Affecting Trust in Market Research Relationship. Journal of Marketing 57(1) : 81-101. 


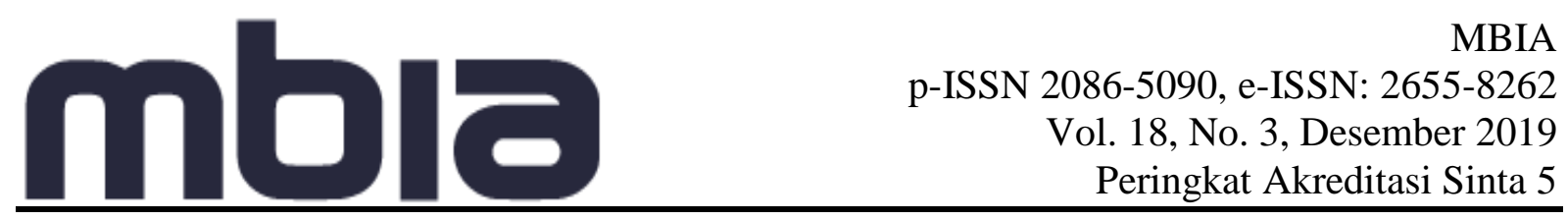

Noefri, Okta dan Andi Hafifah. 2018. Analisis Perilaku Konsumen dalam Melakukan Online Shopping di Di Kota Makasar. Jurnal Manajemen, Ide, Inspirasi (MINDS) 5(1): 113-132

Schiffman and Lazar Kanuk J. I (2001).Costumer behavior. Internasional Edition:Prentice Hall.

Sirdeshmukh, Deepak, Jagdip Singh and Barry Sabol. 2002. Consumer Trust, Value, and Loyalty in Relational Exchanges. Journal of Marketing 66(1) : 15-37 Published by: Sage Publications, Inc. https://www.jstor.org/stable/320336

Sugiyono. 2016. Metode Penelitian Manajemen. Bandung : CV Alfabeta

Tjiptono, Fandy 2008. Strategi Pemasaran, Edisi Ketiga. Yogyakarta: Penerbit CV. Andi Offset.

Verina, Eunike, Edy Yulianto, Wasis A Latief. 2014. Faktor-Faktor yang Mempengaruhi Keputusan Pembelian pada Toko Fashion di Jejaring Sosial Facebook. Jurnal Administrasi Bisnis 10 (1): 1-10 https://media.neliti.com/media/publications/81953-IDfaktor-faktor-yang-mempengaruhi-keputusa.pdf

Wardoyo dan Intan Andini. 2017. Faktor-Faktor yang erpengaruh terhadap Keputusan Pembelian Secara Online pada Mahasiswa Gunadarma. Jurnal Ekonomi Manajemen Sumber Daya 19(1): 12-26

Widiyanto, Ibu \& Prasilowati, Sri Budi. 2015. Perilaku Pembelian Melalui Internet. Jurnal Manajemen dan Kewirausahaan 17(2):109-122

Zeithaml, VA, MJ Bitner, DD Gremler. 2013. Service Marketing : Integrating Customer Focus Across the Firm. Boston : Mc Graw Hill

\section{Copyright Disclaimer}

Copyright for this article is retained by the author(s), with first publication rights granted to the journal. 